\title{
TEACHING XHOSA FOR SPECIAL PURPOSES TO PHYSIOTHERAPY STUDENTS: A CASE STUDY
}

\author{
Alet van Huyssteen \& Bertie Neethling \\ University of the Western Cape
}

Adults generally find language learning difficult and often do not attain much success. This article reports a case study in which a group of learners English and Afrikaans speaking physiotherapy students at the University of the Western Cape learners were allowed to share in the planning of their Xhosa course. Strategies were used to enhance the learner's awareness of their specific communicative needs. Students were then involved in reformulating these needs in terms of desired outcomes. This meant that realistic goals were set with the effect that the objective was seen as attainable. Fear of failure was no longer acute. By participating in the planning process the learners claimed ownership of the course: they experienced a sense of achievement is experienced even before the actual learning process started which strengthened the motivation that had originally led the learner to embark upon the learning exercise.

Dis moeilik vir ' $n$ volwassene om ' $n$ taal aan te leer en resultate is soms onbevredigend. Deur die leerder te betrek by bewusmaking van die spesifieke kommunikatiewe behoeftes wat in terme van gewensde uitkomste geformuleer word, neem die leerder deel aan die beplanning van die kursus. Haalbare doelwitte verwyder die vrees vir mislukking. Deur deelname aan hierdie proses aanvaar die leerder mede-eienaarskap van die kursus en daar is ' $n$ gevoel van prestasie nog voor die leerproses 'n aanvang geneem het. Dit versterk die oorspronklike motivering om die nuwe taal aan te leer.

Hierdie bydrae gaan oor 'n gevallestudie waar Xhosa aan 'n groep Engels- en Afrikaanssprekende fisioterapiestudente aan die Universiteit van Wes-Kaapland onderrig is.

\section{INTRODUCTION}

According to Vivian Cook (1991: 1) 'Language is at the centre of human life ...it is vital to achieving many of our goals and our careers.... Knowing another language may mean: getting a job, a chance to get educated; the ability to take a fuller part in the life of one's own country...'. Barry McLaughlin (1987) takes a similar line. He argues that the increase in studies on second language learning is partially caused by the fact that 'there are more people than ever whose economic aspirations depend on their learning a second language' (McLaughlin 1987:1). Language learning has therefore become part of the lives of millions of people.

Language learning is also somewhat problematic. Van Louw (1999: 54) quotes Reagan, who stated in 1995 that 'Language planning can serve as a tool for empowering groups and 
individuals, .... and for maximizing educational and economical development. However, language planning can also be used to maintain and perpetuate oppression, social class discrimination, and social and educational inequity' (Van Louw 1999:54). She refers to studies that have found that in cases of linguistic diversity language can be regarded as a problem, a right or an asset. These different views on the political role of language are then reflected in language policy.

If the language rights of the individual are protected by a country's constitution, it seems obvious that these rights carry a high premium. Although the constitution may not provide a satisfactory explanation of the psycholinguistic or sociolinguistic theories underlying its views on the nature of language, it is clear that the constitution regards language as an inalienable part of individuals, who are all considered equal. Unless the intention was to continue along the lines of the discredited policy of separate development of the past, the recognition of the language rights of the individual implies the need for individuals to learn languages other than their own in order to be empowered to communicate with their fellow citizens.

The language rights of the individual are neatly protected by South Africa's new constitution. The challenge is to make this work in real life. In a country where the population speaks eleven or more languages, the language rights of the individual can only truly be protected in a supportive multilingual environment. If people are not multilingual, the individual will be restricted in terms of communication to the group of people who speak the same language. One of the basic requirements implied by the inclusion of language rights in the constitution is therefore that people should acquire communicative competence in more than one language.

For the younger generation the education policy should provide for the acquisition of more than one language. The first language should be developed to a level that will enable the learner to function optimally within the educational environment and beyond. There should also be provision for an opportunity to acquire a second language to a level that will enable the learner to communicate effectively in a linguistic environment other than that of the first language. Learners should even be afforded the opportunity to learn more than one language other than the first, if possible.

The real challenge in terms of language acquisition, however, does not only lie in the field of language instruction at primary or secondary school level. The challenge is to deal with the needs of adults who wish to learn a new language. Dulay and his co-authors Burt and Krashen start their book on the issue of second language acquisition as follows:

Learning a second language can be exciting and productive ... or painful and useless. One's efforts can end in the acquisition of native-like fluency or a stumbling repertoire of sentences soon forgotten. The difference often lies in how one goes about learning the new language and how a teacher goes about teaching it. To be successful, a learner need not have a special inborn talent for learning languages. Learners and teachers simply need to "do it right"' (Dulay et al. 1982:3).

The challenge is to find that right way. Although significant advances have been made in the areas of general linguistics, psycholinguistics and cognitive psychology, there is still much to learn about second language learning and McLaughlin warns that there is no one scientific method and no single scientific truth (McLaughlin 1987:1-6). 
Richards and Rodgers explained the concepts 'approaches' and 'methods' in language teaching. According to them, a specific method can be described in terms of the approach it is based on, its design and the procedure that is followed. In their view the term 'approach refers to theories about the nature of language and language learning that serve as the source of practices and principles in language teaching' (Richards and Rodgers 1986:16). Decisions about how to teach language at the levels of approach, design and procedure therefore reflect views on the nature of language and language learning.

Richards views effective language teaching as resulting from 'interactions among the curriculum, teachers, students, methodology, and instructional materials' (Richards 1990:vii). It involves much more than the mere act of teaching. Developing a programme for language learning requires a comprehensive approach. That usually means having a syllabus of some kind. But that too presents problems. Even Nunan (1989: 14-16) who sees syllabus design in fairly conventional terms as the selecting and grading of content, admits that the distinction between syllabus design and methodology is not sustainable when it comes to communicative language teaching. One should first determine why the learners want to learn a language (Nunan 1989:14-16). In these learner-centered approaches the focus is on the learner's needs (Kumaravadivelu 1993:75).

In his article on contemporary paradigms in syllabus design Breen states: 'Any syllabus is primarily a plan of what is to be achieved through teaching and learning. Such a plan, most typically, maps out that body of knowledge and those capabilities which are regarded as worthwhile outcomes from the work of teachers and learners in a particular situation for which the syllabus was designed. In most cases, the plan will specify and select particular aspects of a target language and/or its use in social situations for a range of personal and social purposes. The plan details the objectives or selected outcomes of teaching and learning work. The plan might also address the route towards these objectives and thereby function as a guide during teaching and learning' (Breen 1987:82).

Breen further points out that there are some requirements that should be met by the designer of a syllabus: "The plan must provide an accessible framework of what is to be achieved through teaching and learning which affords continuity and direction for its users. The plan should also function as a retrospective record, a basis for the evaluation of learning, and should itself be amenable to evaluation and adaptation. And the plan must be appropriate to the three contexts of curriculum, classroom group, and educational-social situation within which it is to be located'(op.cit.).

The designer must focus upon, select, subdivide and sequence the knowledge and capabilities chosen as appropriate outcomes of language learning. All this is done against the background of the designer's views on the nature of language and language learning.

McDonough and Shaw pointed out that 'the overall goals of a language teaching programme usually derive from an analysis of the reasons why a group of learners in a particular environment needs to learn' a language, and that 'the possibilities for actually implementing them will be directly related both to the learners themselves - their needs, characteristics and so on - and to the whole educational setting in which the teaching is to take place ... goals need to be realistic for specific circumstances' (McDonough and Shaw 1993:4-5).

They furthermore stated that 'It is possible to identify a number of important learner characteristics or "variables" which .... influence planning decisions and the specification of 
goals.' They name the following characteristics: age, interests, level of proficiency in the target language, aptitude, mother tongue, academic and educational level, attitudes to learning, motivation, reasons for learning, preferred learning styles, and personality (McDonough and Shaw 1993:7-8).

McDonough and Shaw report that during the 1970s the communicative approach was popular. Learning materials had to be geared towards "teaching the learner the appropriate language used for certain functions in meaningful discourse in specific contexts and settings in real-life situations' (p. 25). Authenticity was essential (p. 43).

During the 1990s the need was still the same, but there was also 'recognition of the need to attend to grammar practice, language skills, including study skills, learning of vocabulary and pronunciation, and learning styles' (p. 46). They state that 'The 1990s saw the emergence of the multi-syllabus, which can be viewed as a merging of two broad approaches: the one concerned with language in use, including categories of function, context and language skill, and the other a more formal linguistic syllabus, comprised with elements of grammar, pronunciation and vocabulary' (p. 50). 'Learners now become engaged in both comprehending and producing language' (p. 53). Although language instruction may occur in big classes, individual differences are taken into account. Learner characteristics that may have implications for the language classroom are variables such as personality, motivation, attitude, aptitude, preferred learning styles and intelligence (p. 55).

In terms of learning and acquisition with the distinction one between 'more conscious and logical processes' and the 'spontaneous' acquisition, there is growing acceptance of the view that underlying universal processes are involved in both types of language learning (p.57-58).

More recently syllabus design has dealt with the process of learning - with the focus on 'how' rather than 'what'. The new type of 'process syllabus' cannot be designed completely in advance. It develops around learners' problems and progress in class. It deals with tasks that include information-gap activities, reasoning-gap activities and opinion-gap activities (McDonough and Shaw 1993:60).

With this development in syllabus design the role of the learner has become more prominent. One example is that the learner's needs dictate what happens during the instruction sessions. In the initial stages of language learning it is difficult to implement a process syllabus in its purest form, but one can use the most important features to the advantage of the learners right from the beginning. The basic principle of empowerment underlying language rights could also be the basis for the approach to language instruction.

A great deal of research has also been done on the role of attitudes and motivation in second language learning. It seems that positive attitudes and motivation can be related to success in second language learning. Lightbown and Spada view motivation as a complex phenomenon, which can be defined in terms of learners' communicative needs and their attitude towards the second language community. The need to communicate can cause learners to value the second language and motivate them to acquire proficiency in it (Lightbown and Spada 1993:3).

In terms of curriculum design, therefore, a needs analysis is an important step. According to Pratt 'Needs assessment refers to an array of procedures for identifying and validating needs, and establishing priorities amongst them' (Pratt 1980:79). Following the argument that 
Nobody knows the needs of the adult learners better than the learners themselves, therefore their participation in the design of the syllabus means that an important source of information is utilised.. Furthermore, by involving the learners in an analysis of those needs, the learners' attention is focused on their needs. Larsen-Freeman (1995: 139) points out that it has been proven that 'focusing student attention facilitates intake'. This focusing of attention seems to make a difference even at an early stage when still dealing with needs. An awareness of the needs enforces the original motivation that brought the learners to the decision to start learning the target language. The original feelings of helplessness are replaced by feelings of empowerment through the learners' participation in the syllabus design. The learners view the syllabus as the instrument that will solve their communicative problems and by participating in the process of designing the syllabus they actively participate in the process of solution. The learners claim ownership of the syllabus and develop a very positive attitude towards it. As the course unfolds, learners recognise the contents as what they asked for and therefore as the solution to the problem.

In a discussion of task-based instruction Skehan states 'one of the dilemmas of language teaching: how, on the one hand, to confront the need to engage naturalistic learning processes, while, on the other, to allow the pedagogic processes to be managed in a systematic manner.' He admits that 'language learning is not any sort of simple, linear, cumulative process. Instead, learners must be able to develop their interlanguage systems in more complex ways, through cycles of analysis and synthesis: revisiting some areas as they are seen to require complexification; learning others in a simple, straightforward manner; developing others by simply relexicalizing that which is available syntactically, but which need not be used on such a basis.' He then expresses the hope that, 'however inexact our understanding of language learning, the greatest chance is being created for naturalistic mechanisms to come into play' (Skehan 1996:58).

It is against this background that the requested Xhosa course for the physiotherapy students was conceptualised and constructed. The details of the case study will now follow.

\section{CASE HISTORY}

The Physiotherapy Department at UWC approached the Xhosa Department around mid 2000 to assist them with the following: teaching a short course to first year physiotherapy students that would equip them with basic communication skills in Xhosa. Having taught acquisition courses to various target groups in the past for many years, we (the authors) more or less knew what their needs would be: the students were aspiring physiotherapists that at times would have to interact with Xhosa speaking patients during therapy sessions. It stands to reason that any professional rendering a service to the community, and then particularly on a one-on-one consultation basis would benefit in many ways if that service could be rendered fully (or even partially) in the preferred language of the client. Establishing a sound relationship between medical practitioner and patient is probably one of the prerequisites for harmonious interaction between the two parties. Believing in the medical practitioner who treats you within a relationship of mutual trust is also beneficial regarding the healing process. If the two parties communicate in the preferred language of the patient, this relationship of trust would be strengthened. It was also likely that the general education level of the Xhosa speaking clients (= patients) would vary, ranging from illiterate monolingual customers to those with a high level of education who probably are multilingual, perhaps also speaking the preferred language of the physiotherapist adequately. 
Despite these assumptions, the first step was to conduct a needs analysis among the students to confirm or refute these assumptions. At the first meeting of the students then, we conveyed our eagerness to assist them, but we stressed the fact that we wanted to meet their needs and devise the course in such a way that that objective be attained. This immediately won their approval: by inviting them to be shareholders, so to speak, or co-owners of the enterprise, they indeed felt empowered. Through participating in the syllabus design, Breen's earlier suggestion that the syllabus plan should be 'appropriate to the three contexts of curriculum, classroom group and educational-social situation within which it is to be located' is adhered to. There were some 45 students in the group: only 2 of these had Xhosa as a first language. The rest was either English or Afrikaans speaking, more or less evenly divided. The two Xhosa speaking students were obviously exempted from the course. We advised the other students to use them as living resources and as a sounding board should they need to check, practise, or extend the Xhosa they encountered in class.

Having guided the class through the needs analysis questionnaire, we took the responses home to check. Our former assumptions regarding their specific needs were indeed confirmed. All expressed a desire to communicate with their patients during therapy sessions particularly regarding the treatment session. But it went beyond that. All stressed the fact that they needed to establish a personal relationship with their patients to win their trust and to ensure cooperation, hence gleaning information from patients regarding their personal circumstances at home and just 'making conversation' in general featured very strongly in the questionnaires.

The students had a fairly tight schedule in terms of timetable, but we could eventually negotiate a regular meeting time over 10 weeks, i.e. a fairly short course with 10 contact hours over 10 weeks. This in turn translated into a very tightly constructed syllabus that attempted to address all or most of the expressed needs within the allocated timeframe. As Breen has stated above, a syllabus will usually select particular aspects of the target language and/or its use in social situations for a range of personal and social purposes.

Taking the input of the students into consideration, a rough outline of the syllabus was devised, specifying the desired outcomes of the learning process. A word of warning is perhaps appropriate here: it may, of course, be risky to invite students, particularly inexperienced ones, to contribute towards syllabus design in certain instances. Such students may not have the critical skills that would equip them to make meaningful contributions to syllabus planning. This is often the case with general language acquisition courses where inexperienced students often do not have a clear idea of the contexts in which they would interact with speakers of the target language and their motivation is often limited to a fairly vague 'I want to learn to speak the language'. In the case of the physiotherapy students the case is very different. The group as a whole is career minded and vocationally focused: they want to become suitably qualified and trained physiotherapists. When the group realized that a grasp of basic Xhosa would equip them even better to achieve their goal, learning basic Xhosa within the physiotherapy context was simply another desired outcome within their total curriculum (albeit it voluntary). As a homogeneous group sharing a desired outcome, they obviously then also shared many of the important learner variables or characteristics that McDonough and Shaw referred to. Aside from the personal and individualistic ones like aptitude, mother tongue, and personality, many of the remaining ones they shared, notably 
motivation. It is for that reason that one may very fruitfully involve such a group in codesigning a syllabus.

One should add that it is also true that any language acquisition course to non-speakers with no previous exposure will of necessity include certain basic and constant elements considered necessary for starting and sustaining a conversation. It is only once these have been adequately introduced and covered that one can move to the specific needs of a particular target group.

From the needs analysis responses and our own judgement based on previous experience with similar groups, the following main syllabus constituents were identified. They were presented in the order as listed:

1. Greeting

2. Asking after well being

3. Leave taking

4. Asking after identity

5. Making conversation

i) Questions regarding place of abode

ii) Questions regarding circumstances at home

iii) Questions regarding family setup

iv) Questions regarding travelling

v) Questions regarding the weather

6. Body parts (vocabulary)

7. Complaints (questions)

8. Treatment (instructions)

It was also decided that, should the need arise, this syllabus plan could be adapted and changed. This was in line with Breen's former statement that 'the plan ... should itself be amenable to ... adaptation.' A very important syllabus component that inherently featured in all the syllabus components without it being explicitly specified, was the cultural aspect. A few students indicated their desire to learn more about Xhosa culture in their needs analysis responses. When it was suggested to them that this aspect would be included throughout, there was general consensus. This is obviously a very wide field, hence the decision was taken to focus on culture as it manifested itself in linguistic structures. Where appropriate, other cultural matters were discussed, often prompted by questions from students.

The teaching then started. From the outset it was clear that the students were motivated and they clearly enjoyed the course. As with all groups, there were those students who grasped language specific concepts sooner and more readily than others. It was at this point that particular individualistic learner characteristics manifested. This became clear when students were asked to respond to questions individually, or to become involved in dialogues through role-play. On balance, however, the whole class managed to stay together and to move forward. Every start to a new session was devoted to revision or remedial work. In that way previously taught concepts were practised and internalised. Attendance was quite good except right at the end when the final examinations were looming. This was another sign of ownership.

Once the teaching had been completed, the matter of evaluation was discussed. We suggested that a test by way of an assignment would be taken down. It was further decided that 
participation in this evaluation process would be voluntary, and that the department would issue departmental certificates stating that candidates had attended the course and had satisfied requirements set for the course. Seeing that it was a non-credit bearing short course that had not been registered with SAQA or any other authorizing body, that was the best we could do at the time, but the students were perfectly happy with this arrangement.

A written assignment was decided upon. An oral test was also considered but eventually ruled out: we wanted to simulate interaction between the physiotherapist and a patient, and an oral test involving the lecturers would not have been able to meet that requirement convincingly. It is obviously a good didactic principle that any form of evaluation should have a direct bearing on what was taught, hence the assignment in this case very carefully followed the instruction pattern. Because this was an XSP (Xhosa for Special Purposes course), it made very good sense to follow this line of thinking. The instruction was as follows:

Write an imaginary dialogue between you and a patient that you see for the first time. Your dialogue should contain the following:
a) Greeting
b) Asking after identity
c) Introducing yourself
d) Asking after well being
e) Obtaining personal information from the patient (where s/he lives, with whom, how s/he travels, etc.)
f) Making conversation (e.g. about the weather)
g) Asking about complaint
h) Therapy session (basic instructions regarding treatment)
i) Follow-up arrangements
j) Taking leave

A deadline was set for the handing in of the assignment. Although the assignment was a voluntary exercise, the overwhelming majority of the class handed it in. In some cases it was clear that they had worked together on the assignment, but that did not bother us. It was also clear that some found additional help with the assignment and it may well have been from the two Xhosa speaking students in the class. We welcomed this development: we encouraged them to make use of their Xhosa speaking friends as living resources. This probably also created another form of camaraderie that went beyond that of merely being in the same physiotherapy course together, but now also sharing in cross-cultural matters. When their assistance was discussed with the two Xhosa speaking students, it was also clear that they enjoyed the opportunity of aiding their fellow students and this gave them a sense of pride and dignity.

The quality of the assignments, generally speaking, was of a high standard. It was clear that the students went to a lot of trouble in preparing the assignment. Below follows an example. It is, admittedly, one of the best examples. A translation (in brackets) follows every sentence.

UWendy ufika egumbini lokuxilonga likafizoterapisti (Wendy arrives at the physiotherapist's examination room) 
Physio : Molo nkosazana? Kunjani kuwe? (Good day, miss. How are you?)

Patient : Ewe, molo nkosazana! Kulungile enkosi. Wena, usaphila? (Yes, good day, miss! Fine, thank you. And are you still well?)

Physio : Hayi ndisaphila enkosi. Ndiyifizoterapisti. Ngubani igama lakho? (No, I'm fine, thank you. I am a physiotherapist. What is your name?)

Patient : NdinguWendy. (I am Wendy)

Physio : Ngubani ifani yakho? (What is your surname?)

Patient : Ifani yam nguPatience. (Patience is my surname)

Physio : Ndiyavuya ukukwazi Wendy Patience. Uhlala phi? (Pleased to meet you, Wendy Patience. Where do you live?)

Patient : Ndihlala ePaarl. (I stay in Paarl)

Physio : Usebenza phi? (Where do you work?)

Patient: Andisebenzi, ndisafunda. Ndifundela ukuba ngumbalisi-zimali. (I'm not working, I am still studying. I am studying to become an accountant.)

Physio : Ndingakunceda ngantoni nkosazana? Yintoni? (How can I help you, miss? What's wrong?)

Patient : Andiphilanga. Ndinomqolo nkosazana. Uqale kule mpelaveki iphelileyo. (I'm not well. I have a back problem, miss. It started this past weekend.)

Physio : Ndicela ungene kweli gunjana ukuze ndikuxilonge.(Please go into this room so I can examine you)

Patient : Ingaba uxilongo luza kuba buhlungu. Ndineentloni kuba ndiyaqala ukubonana nefizoterapisti. (Maybe the examination will be painful. I am embarrassed that I have to see a physiotherapist)

Physio : Hayi akukho nto iza kubuhlungu. Musa ukuba nexhala, kuba yonke into iza kulunga. Lala ngesisu. Ubusenza ntoni? (No, nothing will hurt. Don't be afraid, everything will be all right. Lie on your stomach. What did you do?)

Patient : Bendicoca indlu. (I was cleaning the house)

Physio : Lala ngecala...phakamisa...guquka...yekelela...goba....yolula....enkosi! Uziva njani? (Lie on your side...sit up...turn around.. relax....bend.....stretch.....thanks! How do you feel?)

Patient : Andiziva kakuhle. Umqolo uqinile. (I am not feeling well. My back is stiff).

Physio : Mhlawumbi uza kuziva uqinile. Kuza kuba bhetele kwiveki ezayo. Xa ubuya, uza kuziva bhetele. Buyela kum. (Maybe you will be stiff. It will be better next week. When you come back, you will be better. Come back to me.)

Patient : Ewe! Ndiyavuya! (OK! I am happy [now]).

Physio : Ndifowunele wenze isigqibo. (Call me to make an appointment).

Patient : Ewe! Enkosi kakuhle (u)fizoterapist. (Yes! Thanks very much, physiotherapist.)

From this assignment (and the others submitted) one is able to make a few deductions. The students appear to have mastered well the input in terms of course content and particular phrases taught within the physiotherapy context. The assignment encouraged them to go beyond what was required: it is clear that students sought additional help, and in all probability turned to their two Xhosa speaking classmates for help. This is to be welcomed: they were advised from the start to make use of these two students as living resources. At times the structures that were used went well beyond those taught in class in terms of complexity, but they remain functional and appropriate at all times: the assignment remained perfectly coherent and logical. One could perhaps question the use of such structures: had the students internalized them so that they would become part of their spontaneous interaction with Xhosa speaking patients? The answer to that is probably 'no' at this point, but it does 
not exclude the possibility that the students through focusing on these and through repetitive usage may internalise them in time. This is to be welcomed. This does not alter the fact that the students by and large managed through their output to demonstrate that they had mastered the course content. In the example used there are only a few very minor (more editorial) mistakes.

In the final analysis, the experiment has been satisfactory to both parties, teachers and learners. The two main reasons, in our view, are the participatory role that the learners played in designing the syllabus, as well as the fact that they are focused career-minded students that recognised the linguistic diversity of patients they would be encountering in their professional employment context, and hence needed no motivation to address that problem.

The development of XSP courses to such target groups in various contexts is clearly the way forward in the complex multilingual South Africa. One is not aspiring to fluency at this point, but providing basic communication skills within a neatly defined context goes a long way in addressing the often expressed ideal of multilingualism within our country.

\section{REFERENCES}

BREEN, MP. 1987. Contemporary paradigms in syllabus design. Part 1: Language Teaching

COOK, V. 1991. Second language learning and language teaching. Edward Arnold. London.

DULAY, H., M BURT, \& S KRASHEN. 1982. Language Two. Oxford University Press. New York.

KUMARAVADIVELU, B. 1993. The name of the task and the task of naming: Methodological aspects of task-based pedagogy. Crookes, Graham \& SM Gass (eds), Tasks in a pedagogical context: Integrating theory and practice. Clevedon: Multilingual Matters Ltd.

LARSEN-FREEMAN, D. 1995. On the teaching and learning of grammar: Challenging the myths. In Eckman, FR, D Highland, PW Lee, J and W Mileham, \& R Rutkowski (eds), Second Language Acquisition Theory and Pedagogy. Mahwah, New Jersey: Lawrence Erlbaum Associates, Publishers.

LIGHTBOWN, P. M. \& SPADA, N. 1993. How languages are learned. Oxford University Press. Oxford.

MCDONOUGH, J AND SHAW, C. 1993. Materials and methods in ELT. A teacher's guide. Oxford: Blackwell Publishers.

MCLAUGHLIN, B. 1987. Theories of second-language learning. London: Edward Arnold.

NUNAN, D. 1989. Designing tasks for the communicative classroom. Cambridge University Press. Cambridge.

PRATT, D. 1980. Curriculum design and development. Harcourt Brace Jovanovich. New York 
RICHARDS, JC. 1990. The language teaching matrix. Cambridge University Press. Cambridge

RICHARDS, JC AND RODGERS, TS. 1986. Approaches and methods in language teaching. Cambridge University Press. Cambridge.

SKEHAN, P. 1996. A framework for the implementation of task-based instruction Applied Linguistics, 17(1):

VAN LOUW, C. 1999. ' $n$ Ondersoek na die haalbaarheid van dietaaltoevoegingsmodel vir die Suid-Afrikaanse veeltalige konteks:'n histories-strukturele studie Unpublished $\mathrm{PhD}$ thesis, University of the Western Cape, Bellville.

\section{Biographical Note}

Alet van Huyssteen holds an MA in African Languages from Stellenbosch. Her main area of interest is second language acquisition. Currently she is a lecturer in the Xhosa Department at UWC where she has been teaching Xhosa acquisition at different levels for some years. Previously she taught Xhosa as a foreign language at secondary school level. She has also taught Method of Xhosa second language in the Education Faculty at UWC.

Bertie Neethling has a DLitt from Stellenbosch and is professor and chair of the Xhosa Department at UWC. Main areas of interest include Xhosa oral literature, Xhosa names and naming systems (onomastics), and language acquisition. He taught Xhosa acquisition at UPE before moving to UWC, and has been involved with communication courses off-campus to various target groups. 